\title{
ORIGINAL ARTICLE \\ Quality of websites with patient information about spinal cord injury in Spanish
}

\author{
M Bea-Muñoz ${ }^{1}$, M Medina-Sánchez ${ }^{2}$ and MT Flórez-García ${ }^{3}$
}

Study Design: Descriptive, cross-sectional analysis of websites with information on spinal cord injury (SCI) in Spanish. Objective: To assess the quality, readability and presence of quality labels on web pages with information about SCl in Spanish. Setting: The Internet.

Methods: An Internet search was conducted on Google with the keywords 'lesión medular' (spinal cord injury), 'paraplejia' (paraplegia) and 'tetraplejia' (tetraplegia). The first 50 results of each search were included. The quality of websites was assessed with the LIDA tool while the readability was assessed with the Flesch-Szigriszt index and the INFLESZ scale. We also checked the presence of any quality label.

Results: After excluding duplicated and irrelevant results, 33 websites were analysed. Only four of them had a quality label. The mean score of the LIDA tool was $61.12 \%$ (medium quality), and the worst results were those referring to the reliability of the information. The readability of the web pages was somewhat difficult, with a mean of 48.22 in the Flesch-Szigriszt index. Only eight of the websites showed normal readability. We observed no differences in either the quality or the readability of the websites according to their origin or the presence of quality labels.

Conclusions: The websites analysed present a medium quality. Mainly, they should improve the reliability of their contents and their readability, including more quality labels. For SCl information in Spanish to be understandable and to provide valuable content, websites analysed in our study need to improve the quality parameters.

Spinal Cord (2016) 54, 540-545; doi:10.1038/sc.2015.190; published online 20 October 2015

\section{INTRODUCTION}

The Internet has become a usual source of information on medical conditions. ${ }^{1-3}$ In 2013, 44\% of Europeans searched the Internet to read about health issues, $6 \%$ more than that in $2011 .{ }^{4}$ The data for Spain coincide with the European average. ${ }^{4}$ Even though significant social differences and variations between countries in the access to the Internet are still noted, ${ }^{4}$ this network use is likely to increase in the next few years. ${ }^{4-6}$

Spinal cord-injured patients and caregivers are usually in great need of information, especially about health issues. ${ }^{7-10}$ A large part of the inpatient rehabilitation period is engaged in educating the patients to prevent complications that might arise throughout their lifetime. ${ }^{11-13}$ Therefore, although the most reliable information is obtained from health personnel, ${ }^{6,14}$ the Internet might be a good alternative to complement their need for information and education. ${ }^{15,16}$

In the English-speaking world, there are multiple education initiatives for spinal cord-injured patients that take advantage of the ubiquity and multimedia possibilities that the Internet provides. We can find websites with downloadable leaflets, ${ }^{17-19}$ multimedia education programmes, ${ }^{20}$ videos ${ }^{21,22}$ and specific courses on pressure ulcer prevention for spinal cord-injured patients. ${ }^{23}$

Although information on health issues is abundant on the Internet, its impact on the population might be limited owing to the quality of its contents. ${ }^{24,25} \mathrm{~A}$ high percentage of people who use the Internet to search for information on health issues have doubts about the reliability of the information they obtain. ${ }^{1,6}$ Although scientific publications have a quality control system, limiting the publication of biased and fraudulent information, ${ }^{26}$ the quality of health information on the Internet is an unresolved issue. ${ }^{27,28}$ Several evaluation tools have been created, ${ }^{29-33}$ but there is no consensus on which one is the most adequate. ${ }^{34,35}$

In the medical literature, there are many articles about the quality of health-related websites. Generally, their approach is pragmatic, using one tool for evaluating the quality, another for evaluating the readability and, finally, indicating whether the websites show any quality label or certificate. ${ }^{26,36-39}$ Regarding the quality of websites for spinal cord-injured patients, we have only found one article assessing their readability. ${ }^{40}$ The usual conclusion of all these studies, most of them in English, is that the quality and readability of websites offering information for patients should be improved. There is little information about the quality and readability of Internet materials about spinal cord injury (SCI) in Spanish. Only a recent article studies the readability of leaflets and downloadable documents with information on SCI in Spanish. ${ }^{41}$ Therefore, the objective of our study is to search the Internet looking for websites in Spanish with patient information about SCI. Besides this, we are looking to assess the quality of these

${ }^{1}$ Neurological Rehabilitation Unit, Rehabilitation Service, Hospital Universitario Central de Asturias, Oviedo, Spain; ${ }^{2}$ Surgery Department, University of Oviedo, Oviedo, Spain and ${ }^{3}$ Rehabilitation Unit, Foundation Hospital Alcorcón, Madrid, Spain

Correspondence: Dr M Bea-Muñoz, Neurological Rehabilitation Unit, Rehabilitation Service, Hospital Universitario Central de Asturias, Avenida de Roma s/n, 33011, Oviedo, Spain.

E-mail: mbeamedina@gmail.com

Received 7 June 2015; revised 6 September 2015; accepted 20 September 2015; published online 20 October 2015 
websites, analysing their accessibility, usability, reliability, readability and presence of quality labels.

\section{MATERIALS AND METHODS}

Our starting point was to conduct a typical Internet search that anybody interested in obtaining information about SCI in Spanish would do. We searched the Internet using three different keywords: 'lesión medular' (spinal cord injury), 'paraplejia' (paraplegia) and 'tetraplejia' (tetraplegia). The only search engine used was Google (www.google.com) because over 95\% of the searches in Spain are carried out through Google, ${ }^{42,43}$ using as keywords the name of the disease or one of the symptoms. ${ }^{44,45}$ The dates of the searches were 13 and 14 June 2014, and the first 50 results were reviewed in each search (five Google pages), making a total of 150 pages retrieved. We considered relevant results for our study those websites offering information about what SCI, paraplegia or tetraplegia are, as well as their causes, their consequences and recommendations about treatment and care. We excluded dictionaries, news, videos, scientific articles, social networking sites, scientific societies and any other result whose information did not meet the inclusion criteria or were considered irrelevant.

First of all, we classified the websites according to their origin, distinguishing five types: Associations and foundations; hospitals, universities and institutional websites; commercial websites; blogs; and online encyclopaedias.

We evaluated three criteria to study the quality of websites: LIDA tool results, content readability and presence of quality labels.

\section{The LIDA tool}

The LIDA tool (version 1.2, Minervation Ltd, Oxford, UK) ${ }^{46}$ is a validated instrument for assessing websites providing health-related information. This tool is accessible free of charge at http://www.minervation.com/lida-tool/ accessibility/. It evaluates three areas: accessibility, usability and reliability.

Web accessibility means that people with disabilities can perceive, understand, navigate and interact with the Web, and that they can contribute to the Web. ${ }^{47}$ The LIDA tool assesses accessibility using an automated check, typing the URL address of the website we want to analyse. The online tool looks at the HTML and metadata of the web page and scans for common errors that may affect accessibility. ${ }^{48}$ The score corresponds to the percentage of compliance with the accessibility requirements.

Website usability depends on the ease of browsing the content. Therefore, for a website to be usable, it needs to show a clear design and a structure that makes navigation easy and intuitive. Usability concerns whether the information is designed and structured in such a way that the user can get what they want from it. This means that there must be a clear method of organising the information, and it must be clear to the user what they need to do to get what they want. ${ }^{49}$ Table 1 shows the items and scoring of this section. The usability score is the percentage of the maximum points possible in the section.

Table 1 Questions and scores of the LIDA tool regarding usability and reliability

\section{Usability}

Is the site design clear and transparent?

Is the site design consistent from one page to another?

Can users find what they need on the site?

Is the format of information clear and appropriate for the audience?

Score: 0 , never; 1 , sometimes; 2 , mostly; 3 , always.

\section{Reliability}

Is it clear who has developed the website and what their objectives are?

Does the site report a robust quality control procedure?

Is the page content checked by an expert?

Is the page updated regularly?

Does the page cite relevant sources where appropriate?

Score: 0 , never; 2 , sometimes; 4 , mostly; 6 , always.
Website reliability depends on the transparency and relevance of its contents, the absence of conflicts of interests or reporting bias, the experts involved in the creation of the website and the regular updating of contents. Websites do not just have to ensure that they are reliable, but they also have to show how they produce their content so that users can develop a sense of trust in them. ${ }^{50}$ Table 1 also shows the items relating to this section, and the scoring system is similar to that used for usability.

The LIDA tool offers criteria and recommendations to score these questions. ${ }^{46}$ Finally, it also offers an overall score that combines the results of all three different sections. So, the LIDA tool can be used as a quantitative measure of quality to rank or compare many different sources or as a tool to assess individual pages or to assess a website as a whole. ${ }^{48}$ Scores higher than $90 \%$ are considered as high quality, scores between 50 and $90 \%$ as medium quality, and scores lower than $50 \%$ as low quality. ${ }^{46}$

\section{Readability, the INFLESZ program}

Readability measures whether a text is easy to read and understand. Typographical readability, which depends on the font and layout, is different from linguistic readability, which is related to the grammatical structure of the texts. ${ }^{51}$ For texts to be easy to read, they must use plain language and short sentences, and avoid circumlocutions and complex sentences. ${ }^{51,52}$

The first formulas to study linguistic readability were designed for the English language. More than 40 readability formulas exist, such as the Fry, Flesch, Flesch-Kincaid and Simple Measure of Gobbledygook (SMOG), which are used extensively in health care. ${ }^{53}$ All these formulas are used in a similar way, counting up syllables, words and phrases of the analysed text, and applying the appropriate algorithm. ${ }^{54}$ However, the Spanish language structure is different from the English structure, so it is necessary to adapt the formulas to use them in Spanish texts. The most recent adaptation of the Flesch scale into Spanish is the Flesch-Szigriszt index. ${ }^{55}$ The formula used is 206.835 $62.3 \mathrm{~S} / \mathrm{W}$ - W/P, in which $\mathrm{S}$ corresponds to the total number of syllables of the text, $\mathrm{W}$ to the total number of words and $\mathrm{P}$ to the total number of phrases. The Flesch-Szigriszt index scores from 0 to 100 points. The higher the score, the easier it is to read. In 2008, Barrio-Cantalejo et al..$^{56}$ developed the INFLESZ scale to interpret the scoring of Flesch-Szigriszt index, adapting it to the reading habits of the Spanish population. Table 2 shows the INFLESZ scale grades. A score equal or higher than 55 indicates that texts have a normal or easy readability for the Spanish reader. ${ }^{56}$ To assess the readability of the websites, we have used the Flesch-Szigriszt index together with the INFLESZ scale, both available in the INFLESZ program, which is free of charge. ${ }^{57}$

The entire text was analysed if the information was displayed in one to three web pages, whereas only three pages, selected by a virtual random number generator, ${ }^{58}$ were analysed if the information was displayed in more than three web pages. The text was edited following recommendations outlined in the readability literature: ${ }^{59}$ Unwanted elements such as advertisements, authors, links or bibliography were removed. Line breaks, colons, semicolons and dashes were also removed to avoid the interference of such elements in skewing the readability results.

\section{Quality labels}

These are certificates shown by some websites and displayed as seals, labels or logotypes that are endorsed by various institutions to indicate that the website complies with specific codes of ethics or quality. ${ }^{60}$ The best known is 'Health On the Net' (HON), created by the Health On the Net Foundation. ${ }^{61}$ In Spain, the 'Web Médica Acreditada' (Accredited Medical Website) certificate is endorsed by the medical association Colegio de Médicos de Barcelona. ${ }^{62}$ The Agencia de Calidad Sanitaria de Andalucía (Andalusian Agency for Healthcare Quality) has also implemented a system for website accreditation. ${ }^{63}$ In this paper, we point out whether the websites studied have any quality label or not.

We have carried out a descriptive analysis of all quantitative variables, indicating the arithmetic mean, the maximum and minimum values, and the standard deviation. For qualitative variables, we indicate the absolute value and its percentage. Besides, we have compared the LIDA tool scores of the websites that have quality standards with those that do not have them using the MannWhitney test; in addition, we have compared the LIDA tool scores of the different types of websites according to their origin using the Kruskal-Wallis 
Table 2 INFLESZ scale

\begin{tabular}{lrl}
\hline Grade & Score & Type of publication \\
\hline $\begin{array}{l}\text { Very difficult } \\
\text { Somewhat difficult }\end{array}$ & $0-40$ & $\begin{array}{l}\text { University or scientific publication } \\
\text { Baccalaureate, popular science, science } \\
\text { journalism }\end{array}$ \\
Normal & $55-65$ & $\begin{array}{l}\text { Secondary school, general press, sports } \\
\text { journalism }\end{array}$ \\
Quite easy & $65-80$ & $\begin{array}{l}\text { Primary school, tabloids, bestsellers } \\
\text { Very easy }\end{array}$ \\
\hline
\end{tabular}

test. We have also compared readability results according to the presence of quality labels or the type of website by using the statistics tests Student's $t$-test and one-way analysis of variance, respectively. The level of statistical significance was $P<0.05$. We used the statistical software MedCalc 13.1.2 (MedCalc Software bvba, Ostend, Belgium; http://www.medcalc.org; 2014).

\section{RESULTS}

Out of 150 websites, 43 met the inclusion criteria. After excluding duplicated pages, 33 websites were left to be analysed (Table 3). Of these 33 websites, 5 (15.15\%) belonged to associations and foundations, $6(18.18 \%)$ were blogs, $5(15.15 \%)$ were commercial websites,

Table 3 Web pages studied, ordered by their LIDA Overall Score

\begin{tabular}{|c|c|c|c|c|c|c|c|c|}
\hline & LIDA OS & Accessibility & Usability & Reliability & F-S Index & $\begin{array}{c}\text { INFLESZ } \\
\text { Scale }\end{array}$ & $\begin{array}{c}\text { Q. } \\
\text { Label }\end{array}$ & TYPE \\
\hline www.neurowikia.es/content/tetraplejia & 77 & 91 & 75 & 53 & 31.42 & VD & no & E \\
\hline www.medtronic.es/su-salud/lesion-medular/index.htm & 75 & 98 & 75 & 33 & 46.15 & SD & no & C \\
\hline www.luzverde.com.uy/la-paraplejia-y-sus-causas/ & 68 & 98 & 67 & 13 & 57.75 & $\mathrm{~N}$ & no & B \\
\hline $\begin{array}{l}\text { salud.discapnet.es/CASTELLANO/SALUD/RECURSOS/FAQS/Paginas/FAQS } \\
\text { Lesion medular.aspx }\end{array}$ & 66 & 94 & 67 & 13 & 48.38 & SD & no & E \\
\hline $\begin{array}{l}\text { www.monografias.com/trabajos16/medula-espinal-paraplejia/medula-espinal- } \\
\text { paraplejia.shtml }\end{array}$ & 65 & 89 & 67 & 20 & 48.94 & SD & no & E \\
\hline tratado.uninet.edu/c1106i.html & 65 & 72 & 58 & 53 & 39.6 & VD & no & E \\
\hline $\begin{array}{l}\text { www.regmurcia.com/servlet/s.SI?sit =c,316\&r }=\text { ReP-14181- } \\
\text { DETALLE_REPORTAJES }\end{array}$ & 64 & 94 & 67 & 7 & 58.49 & $\mathbf{N}$ & no & $\mathrm{H} / \mathrm{U}$ \\
\hline www.med.nyu.edu/content?ChunkIID = 127567 & 64 & 76 & 67 & 40 & 42.83 & SD & no & $\mathrm{H} / \mathrm{U}$ \\
\hline $\begin{array}{l}\text { www.infomedula.org/index. php? } \\
\text { option }=\text { com_content\&view }=\text { article\&id }=177 \& \text { ltemid }=123 \& \text { lang }=\text { es }\end{array}$ & 62 & 89 & 83 & 7 & 49.19 & SD & no & $\mathrm{H} / \mathrm{U}$ \\
\hline www.who.int/mediacentre/factsheets/fs384/es/ & 62 & 89 & 67 & 13 & 38.58 & VD & no & $\mathrm{H} / \mathrm{U}$ \\
\hline es.wikipedia.org/wiki/Lesión_de_la_médula_espinal & 62 & 83 & 75 & 20 & 51.35 & SD & no & E \\
\hline es.wikipedia.org/wiki/Paraplejía & 62 & 83 & 75 & 20 & 44.43 & SD & no & E \\
\hline es.wikipedia.org/wiki/Tetraplejía & 62 & 83 & 75 & 20 & 58.1 & N & no & E \\
\hline www.fenexy.org & 62 & 87 & 75 & 13 & 53.69 & SD & WMA & A \\
\hline $\begin{array}{l}\text { www.drugs.com/cg_esp/paraplejía-después-de-una-lesión-en-la-médula-espinal- } \\
\text { aftercare-instructions.html }\end{array}$ & 61 & 87 & 67 & 13 & 61.87 & N & HON & E \\
\hline www.imedir.udc.es/participa/ & 61 & 85 & 42 & 27 & 35.21 & VD & no & $\mathrm{H} / \mathrm{U}$ \\
\hline www.paravan.de/es/servicio/cuadros-clinicos/tetraplejia.html & 60 & 94 & 42 & 7 & 52.14 & SD & no & C \\
\hline www.news-medical.net/health/Paraplegia-What-is-Paraplegia-(Spanish).aspx & 60 & 91 & 58 & 7 & 49.69 & SD & no & E \\
\hline www.tecnoapoyo.es/tetraplejia.htm & 60 & 89 & 50 & 7 & 57.02 & $\mathrm{~N}$ & no & C \\
\hline paraplejia2.blogspot.com.es/ & 60 & 81 & 67 & 20 & 44.32 & SD & no & B \\
\hline www.guttmann.com/es-es/hospital/la-neurorrehabilitacion/la-lesion-medular.html & 59 & 87 & 67 & 7 & 50.82 & SD & $\begin{array}{l}\text { WMA } \\
\text { HON }\end{array}$ & $\mathrm{H} / \mathrm{U}$ \\
\hline disgoo.com/profiles/blogs/m-dula-espinal-paraplej-a & 59 & 87 & 50 & 13 & 46.1 & SD & no & B \\
\hline fundacionbelen.org/base-datos/lesion-medular/ & 59 & 87 & 50 & 13 & 55.58 & N & no & A \\
\hline $\begin{array}{l}\text { www.minusval2000.com/relaciones/ArchivosRelaciones/sexualidad_en_perso- } \\
\text { nas_con_lesion_medular.html }\end{array}$ & 59 & 81 & 42 & 27 & 54.22 & SD & no & B \\
\hline $\begin{array}{l}\text { www.medicina21.com/Articulos/V1284-Saber_mas_sobre_la_paraplejia_espasti- } \\
\text { ca_hereditaria.html }\end{array}$ & 59 & 69 & 67 & 40 & 12.62 & VD & HON & B \\
\hline www.lesionmedular.es/ & 58 & 87 & 58 & 7 & 54.2 & SD & no & C \\
\hline www.medulardigital.com/ & 57 & 87 & 50 & 7 & 45.97 & SD & no & A \\
\hline www.lesionmedular.org/ & 57 & 83 & 67 & 7 & 56.92 & N & no & B \\
\hline www.fundacionstepbystep.com/ & 57 & 80 & 67 & 13 & 49.97 & SD & no & A \\
\hline $\begin{array}{l}\text { www.postpolio-efectos-secundarios-del-la-polio.org/article-tetraplejia-hemiplejia- } \\
\text { la-medula-espinal-119410402.html }\end{array}$ & 56 & 83 & 42 & 13 & 56.13 & $\mathrm{~N}$ & no & A \\
\hline www.allinahealth.org/mdex_sp/SD7170G.HTM & 55 & 76 & 67 & 13 & 54.15 & SD & no & $\mathrm{H} / \mathrm{U}$ \\
\hline www.adaptauto.com/tetraplejia.html & 53 & 80 & 50 & 7 & 47.2 & SD & no & C \\
\hline www.terapia-fisica.com/tratamiento-de-la-lesion-medular.html & 51 & 76 & 50 & 7 & 38.52 & VD & no & E \\
\hline
\end{tabular}

Abbreviations: A, associations and foundations; B, blogs; C, commercial websites; E, online encyclopaedias; H/U, hospitals, universities and institutional websites; F-S Index, Flesch-Szigriszt Index; HON, Health On the Net; LIDA OS, LIDA Overall Score; N, normal; Q.Label, Quality Label; SD, somewhat difficult; TYPE, type of web page; VD, very difficult; WMA, Web Médica Acreditada. Web pages with quality labels are highlighted in bold. Web pages with normal readability are highlighted in bold. 
$10(30.30 \%)$ were online encyclopaedias, and $7(21.21 \%)$ belonged to hospitals, universities and official institutions. Only 4 out of the $33(12.12 \%)$ showed quality labels. Further details are shown in Table 3.

The LIDA tool scores varied between 51 and 77\%, the mean being $61.12 \%$ (medium quality). Accessibility results were the best, with a mean of $85.33 \%$ (medium quality). Reliability results were the worst, with a mean score of 17.57 and $93.93 \%$ of the websites scoring below $50 \%$. The LIDA tool results are summarized in Tables 3 and 4. Websites that had quality labels showed no quality differences in comparison with those that did not have them (Table 5). There was also no quality differences according to the type of website (Table 6).

The Flesch-Szigriszt readability index of the studied websites varied between 12.62 (very difficult) and 61.87 (normal), the mean being 48.22, which indicated that they were somewhat difficult texts. Only eight websites (24.24\%) showed a normal readability, 19 $(57.57 \%)$ showed a somewhat difficult readability and up to 6 websites $(18.18 \%)$ showed a very difficult readability. These values are also detailed in Tables 3 and 4 . Websites that had quality labels showed no difference in readability in comparison with those that did not have them (Table 5), and neither did the different types of websites (Table 6).

Table 4 Description of the studied quantitative variables

\begin{tabular}{lcccr}
\hline & Minimum & Maximum & Mean & s.d. \\
\hline LIDA OS & 51 & 77 & 61.12 & 5.26 \\
Accessibility & 69 & 98 & 85.33 & 6.87 \\
Usability & 42 & 83 & 62 & 11.58 \\
Reliability & 7 & 53 & 17.57 & 12.99 \\
F-S Index & 12.62 & 61.87 & 48.22 & 9.64 \\
\hline
\end{tabular}

Abbreviations: LIDA OS, LIDA Overall Score; F-S Index, Flesch-Szigriszt Index.

Table 5 Comparison of LIDA OS and F-S Index scores obtained by websites with and without quality labels

\begin{tabular}{lccc} 
& $\begin{array}{c}\text { Websites with } \\
\text { quality label } \\
(\mathrm{n}=4)\end{array}$ & $\begin{array}{c}\text { Websites without } \\
\text { quality label } \\
(\mathrm{n}=29)\end{array}$ & $\mathrm{P}$ \\
\hline LIDA OS Mean (s.d.) & $61.24(5.59)$ & $60.25(1.50)$ & 0.78 \\
F-S Index Mean (s.d.) & $48.70(7.27)$ & $44.75(21.92)$ & 0.74 \\
\hline
\end{tabular}

Abbreviations: LIDA OS, LIDA Overall Score; F-S Index, Flesch-Szigriszt Index.

\section{DISCUSSION}

There is little information available on the quality of educational websites for spinal cord-injured patients. We have only found one article that analyses the readability of web pages offering information about SCI. ${ }^{40}$ In our study, we have used measurements and criteria similar to those used in other articles that assess the quality and readability of health-related websites. ${ }^{26,36-38}$

The LIDA tool has already been used for assessing websites in Spanish, ${ }^{39}$ showing shortcomings in accessibility, usability and reliability. In our study, the global score of the LIDA tool shows intermediate-quality websites (Tables 3 and 4). The highest scores were in accessibility, with seven websites above $90 \%$ and a mean score of $85.33 \%$. Accessibility analyses whether the content of the website is accessible to everyone, even if the person has a disability. In contrast, reliability had the lowest score. This indicates that websites do not mention the authors, the origin of the contents or the date when the information was updated. Usability shows the ease to browse the webpage and had medium quality, with a mean score of $62 \%$. Our results coincide with other studies about the quality of websites, with higher results in accessibility and lower results in reliability. ${ }^{39,64}$

The Flesch index is widely used to measure the readability of websites and documents in English. ${ }^{26,36-38}$ We have used its most recent adaptation to Spanish, the Flesch-Szigriszt index, which is included in the INFLESZ programme. ${ }^{57}$ This software has been used to study the readability of informed consent documents and patient information leaflets in several Spanish publications. ${ }^{65-68}$ Another Spanish article ${ }^{54}$ analysed the readability of websites of seven chronic diseases with a previous Spanish adaptation of the Flesch index, showing that their readability was not optimal. A recent study about readability of downloadable documents from the Internet with information about SCI in Spanish reveals a somewhat difficult readability and a mean of 51.56 in the Flesch-Szigriszt index. ${ }^{41}$ In our study, the mean of the Flesch-Szigriszt index is 48.22, which indicates a somewhat difficult readability according to the INFLESZ scale. The above mentioned study ${ }^{40}$ about the readability of English websites offering information to spinal cord-injured patients obtained an average of 40.2 in the Flesch index and a Flesch-Kincaid score of 11.9, which is far above the average reading level of the American population, between 7 th and 8 th grade. ${ }^{69}$

Quality standards or labels are another criterion that is normally used by websites to prove their value and compliance with ethical principles. In our search, only four websites showed quality standards, especially the Health On the Net (HON) label, which is shown in three of them (Table 3). Several studies have shown that certified websites have significantly greater LIDA and quality scores than uncertified ones. ${ }^{26,37,60}$ In contrast, our study has not observed significantly higher scores of the LIDA tool in the four websites with quality labels (Table 5).

We acknowledge that our study has some limitations. Firstly, the changing nature of the Internet makes the search results difficult to be repeated. Searching with different search engines, other terms or on

Table 6 Comparison of LIDA OS and F-S Index scores obtained depending on the origin of the websites

\begin{tabular}{|c|c|c|c|c|c|c|}
\hline & Associations/Foundations $\mathrm{n}=5$ & $B \operatorname{logs} \mathrm{n}=6$ & Commercial $\mathrm{n}=5$ & Encyclopaedias $\mathrm{n}=10$ & Hospital/University $\mathrm{n}=7$ & $\mathrm{P}$ \\
\hline LIDA OS Mean (s.d.) & $58.20(2.38)$ & $60.33(3.88)$ & $61.20(8.22)$ & $63.10(6.43)$ & $61(3.16)$ & 0.15 \\
\hline F-S Index Mean (s.d.) & $52.66(4.26)$ & $45.32(16.96)$ & $51.34(4.61)$ & $47.23(9.13)$ & $47.03(8.46)$ & 0.73 \\
\hline
\end{tabular}

Abbreviations: LIDA OS: LIDA Overall Score. F-S Index: Flesch-Szigriszt Index. 
different days may vary the results. ${ }^{70}$ In our Internet search, we tried to reproduce the usual pattern that a Spanish person looking for information about SCI would follow: over $95 \%$ of the searches in Spain are made through Google $e^{42,43}$ by entering the name of the disease or one of the symptoms. ${ }^{44,45}$ We believe that analysing five Google results pages is thorough enough, especially because the general population usually does not search beyond the second page. ${ }^{71,72}$ Secondly, the quality of websites and how to assess it is a controversial and unresolved issue. ${ }^{25,28}$ Furthermore, quality has a subjective component that is difficult to quantify. ${ }^{25}$ For our study, we have used a valid tool ${ }^{46}$ that is widely used in both English ${ }^{36-38}$ and Spanish $^{39}$ studies. Thirdly, something similar could be said about readability. It is difficult to reduce the ease of reading a text to a mathematical formula. ${ }^{59}$ However, readability indexes are a wellaccepted approach to improve the reading and comprehension of a text. ${ }^{55,73}$ Finally, we have not assessed whether the information and contents on SCI of the web pages are appropriate, accurate and sufficient.

Therefore, we conclude that the websites offering information on SCI in Spanish have medium quality and need to improve mostly their content reliability and readability. The quality labels are present in a few websites and their inclusion could also be an encouragement to improve the quality of the web pages and the confidence in their content. If we want the information on spinal cord injuries presented in websites in Spanish to be understood and offer valuable content, website creators need to know and improve the quality parameters we have analysed in our study.

\section{DATA ARCHIVING}

There were no data to deposit.

\section{CONFLICT OF INTEREST}

The authors declare no conflict of interest.

1 Los ciudadanos ante la e-Sanidad. Estudio sobre opiniones y expectativas de los ciudadanos sobre el uso y aplicación de las TIC en el ámbito sanitario. Observatorio Nacional de las Telecomunicaciones y de la Sociedad de la Información (ONTSI). Available at www.ontsi.red.es/ontsi/sites/default/files/informe_ciudadanos_esanidad.pdf Accessed February 8, 2015.

2 Villaescusa Martínez V, Sáez Villar L. Búsqueda de información sobre salud a través de internet. Enferm Glob 2013; 12: 197-205.

3 Marín-Torres V, Valverde Aliaga J, Sánchez Miró I, Sáenz del Castillo Vicente MI, Polentinos-Castro E, Garrido Barral A. Internet como fuente de información sobre salud en pacientes de atención primaria y su influencia en la relación médico-paciente. Aten Primaria 2013; 45: 46-53.

4 Individuos que usan internet para buscar información relacionada con la salud, 2007-2013. Observatorio Nacional de las Telecomunicaciones y de la Sociedad de la Información (ONTSI). Available at www.ontsi.red.es/ontsi/es/node/334 Accessed February 8, 2015.

5 Kummervold PE, Wynn R. Health information accessed on the Internet: the development in 5 European countries. Int J Telemed App/ 2012; 2012: 297416.

6 Matter B, Feinberg M, Schomer K, Harniss M, Brown P, Johnson K. Information needs of people with spinal cord injuries. J Spinal Cord Med 2009; 32: 545-554.

7 Hart KA, Rintala DH, Fuhrer MJ. Educational interests of individuals with spinal cord injury living in the community: medical, sexuality, and wellness topics. Rehabil Nurs 1996; 21: 82-90.

8 Anderson KD. Targeting recovery: priorities of the spinal cord-injured population. J Neurotrauma 2004; 2: 1371-1383.

9 May L, Day R, Warren S. Evaluation of patient education in spinal cord injury rehabilitation: Knowledge, problem-solving and perceived importance. Disabil Rehabil 2006; 28: 405-413.

10 Norman C, Bender JL, Macdonald J, Dunn M, Dunn S, Siu B et al. Questions that individuals with spinal cord injury have regarding their chronic pain: A qualitative study. Disabil Rehabil 2010; 32: 114-124.

11 Zemper ED, Tate DG, Roller S, Forchheimer M, Chiodo A, Nelson VS et al. Assessment of a Holistic Wellness Program for Persons with Spinal Cord Injury. Am J Phys Med Rehabil 2003; 82: 957-968.
12 Cardenas DD, Hoffman JM, Kelly E, Mayo ME. Impact of a urinary tract infection educational program in persons with spinal cord injury. J Spinal Cord Med 2004; 27: 47-54.

13 Gélis A, Stéfan A, Colin D, Albert T, Gault D, Goossens D et al. Therapeutic education in persons with spinal cord injury: A review of the literature. Ann Phys Rehabil Med 2011; 54: 189-210.

14 Burkell JA, Wolfe DL, Potter PJ, Jutai JW. Information needs and information sources of individuals living with spinal cord injury. Health Info Libr J 2006; 23: 257-265.

15 Gremeaux V, Coudeyre E. The internet and the therapeutic education of patients: A systematic review of the literature. Ann Phys Rehabil Med 2010; 53: 669-692.

16 Gill HK, Gill N, Young SD. Online technologies for health information and education: a literature review. J Consum Health Internet 2013; 17: 139-150.

17 Spinal Cord Medicine Patient \& Family Education. KentuckyOne Health. Available at http://www.kentuckyonehealth.org/spinal-cord-medicine-patient-family-education Accessed February 8, 2015.

18 Spinal Cord Injury Patient - Family Teaching Manual. Jefferson University Hospital. Magee Rehabilitation. Available at www.spinalcordcenter.org/consumer/manual.html Accessed February 8, 2015.

19 Delparte JJ, Chau BA, Mills S, Burns AS. Spinal cord essentials: the development of an individualized, handout-based patient and family education initiative for people with spinal cord injury. Spinal Cord 2014; 52: 400-406.

20 Shepherd JD, Badger-Brown KM, Legassic MS, Walia S, Wolfe DL. SCI-U: E-Learning for patient education in spinal cord injury rehabilitation. J Spinal Cord Med 2012; 35: 319-329.

21 Hoffman J, Salzman C, Garbaccio C, Burns SP, Crane D, Bombardier C. Use of ondemand video to provide patient education on spinal cord injury. J Spinal Cord Med 2011; 34: 404-409.

22 The University of Alabama Spinal Cord Injury Model System (UAB-SCIMS) Information Network. Available at www.uab.edu/medicine/sci/ Accessed February 8, 2015.

23 Schubart J. An E-Learning program to prevent pressure ulcers in adults with spinal cord injury: a pre- and post-Pilot test among rehabilitation patients following discharge to home. Ostomy Wound Manag 2012; 58: 38-49.

24 Solé Balcells FJ. Internet en medicina. Una ayuda, un problema, una causa de errores? Actas Urol Esp 2003; 27: 180-184.

25 Jiménez Pernett J, García Gutiérrez JF, Martín Jiménez JL, Bermudez Tamayo C. Tendencias en el uso de Internet como fuente de información sobre salud. UOC Papers 2007; 4: 44-50.

26 Tavare AN, Alsafi A, Hamady MS. Analysis of the quality of information obtained about uterine artery embolization from the Internet. Cardiovasc Intervent Radiol 2012; 35: 1355-1362.

27 Risk A, Petersen C. Health information on the Internet. JAMA 2002; 287: 2713-2715.

28 Deshpande A, Jadad AR. Trying to measure the quality of health information on the internet: is it time to move on. J Rheumatol 2009; 36: 1-3.

29 Gagliardi A, Jadad AR. Examination of instruments used to rate quality of health information on the internet: chronicle of a voyage with an unclear destination. BMJ 2002; 324: 569-573.

30 Eysenbach G, Powell J, Kuss O, Sa E. Empirical studies assessing the quality of health information for consumers on the world wide web. JAMA 2002; 287: 2691-2700.

31 Bermúdez-Tamayo C, Jiménez-Pernett J, García-Gutiérrez JF, Azpilicueta Cengotitobengoa I, Silva-Castro MM, Babio G et al. Cuestionario para evaluar sitios web sanitarios según criterios europeos. Aten Primaria 2006; 38: 268-274.

32 Rees CE, Ford JE, Sheard CE. Evaluating the reliability of DISCERN: a tool for assessing the quality of written patient information on treatment choices. Patient Educ Couns 2002; 47: 273-275.

33 The Minervation validation instrument for healthcare websites (LIDA tool). Available at www.minervation.com/lida-tool/ Accessed February 8, 2015.

34 Ramos Sánchez E Criterios más utilizados para la evaluación de la calidad de los recursos de información en salud disponibles en Internet. ACIMED [serial online]. April 2004;12:1-1. Available at http://scielo.sld.cu/scielo.php?script=sci_arttext\&pid = S1024-94352004000200004\&Ing =es Accessed February 8, 2015.

35 Conesa Fuentes MC, Aguinaga Ontoso E Evaluación de la calidad de las páginas web con información sanitaria: una revisión bibliográfica. Available at www2.ub.edu/bid/23/ pdf/conesa2.pdf?origin = publication_detail Accessed February 8, 2015.

36 Soobrah R, Clark SK. Your patient information website: how good is it? Colorectal Dis 2012; 14: e90-e94.

37 Grewal P, Alagaratnam S. The quality and readability of colorectal cancer information on the internet. Int J Surg 2013; 11: 410-413.

38 Goslin RA, Elhassan HA. Evaluating internet health resources in ear, nose, and throat surgery: Evaluating ENT Internet Health Resources. Laryngoscope 2013; 123: 1626-1631.

39 San Norberto EM, Taylor J, Salvador R, Revilla A, Merino B, Vaquero C. Calidad de la información disponible en internet sobre el aneurisma de aorta y su tratamiento endovascular. Rev Esp Cardiol 2011; 64: 869-875.

40 Agarwal N, Hansberry DR, Singh PL, Heary RF, Goldstein IM. Quality assessment of spinal cord injury patient education resources. Spine 2014; 39: E701-E704.

41 Bea-Muñoz M, Medina-Sánchez M, Flórez-García M. Legibilidad de los documentos informativos en español dirigidos a lesionados medulares y accesibles por Internet. An Sist Sanit Navar 2015; 38: 255-262.

42 Search Engine Barometer, May 2014. The search engine market in France, Germany, Spain and United Kingdom. Available at www.atinternet.com/en/documents/searchengine-barometer-may-2014/ Accessed February 8, 2015. 
43 ¿Cuáles son los navegadores y buscadores que más se utilizan en el mundo?. Available at www.webyposicionamientoseo.com/cuales-son-los-navegadores-y-buscadores-quemas-se-utilizan-en-el-mundo.blog Accessed February 8, 2015

$44 \mathrm{~A}$ literature review on health information-seeking behaviour on the web: a health consumer and health professional perspective. European Centre for Disease Prevention and Control. Available at http://ecdc.europa.eu/en/publications/Publications/Literature \%20review\%20on\%20health\%20information-seeking\%20behaviour\%20on\%20the\% 20web.pdf Accessed February 8, 2015.

45 Encuesta Pfizer. El rol de Internet en el proceso de consulta de información sobre salud. September 2010. Available at www.pfizer.es/docs/pdf/noticias/Resultados_encuesta_Pfizer.pdf Accessed February 8, 2015.

46 The LIDA Instrument. Minervation validation instrument for health care web sites. Ful Version (1.2) containing instructions. Available at www.minervation.com/wp-content/ uploads/2011/04/Minervation-LIDA-instrument-v1-2.pdf Accessed February 8, 2015.

47 Introduction to web accesibility. Available at www.w3.org/WAl/intro/accessibility.php Accessed February 8, 2015.

48 Category Archives: LIDA. Available at www.minervation.com/category/lida/ Accessed February 8, 2015.

49 Usability. Available at www.minervation.com/lida-tool/usability/ Accessed February 8 , 2015.

50 Reliability. Available at www.minervation.com/lida-tool/reliability/ Accessed February 8, 2015

51 Ferrando Belart V. La legibilidad: un factor fundamental para comprender un texto. Aten Prim 2004; 34: 143-146.

52 Barrio IM, Simón-Lorda P, Melguizo M, Molina A. Consenso sobre los criterios de legibilidad de los folletos de educación para la salud. An Sist Sanit Navar 2011; 34: $153-165$.

53 Wilson FL, Williams BN. Assessing the readability of skin care and pressure ulcer patient education materials. J Wound Ostomy Continence Nurs 2003; 30: 224-230.

54 Blanco Perez A, Gutierrez Couto U. Legibilidad de las páginas web sobre salud dirigidas a pacientes y lectores de la población general. Rev Esp Salud Publica 2002; 76 : $321-331$.

55 ¿Que es la legibilidad?. Available at www.legibilidad.com/home/acercade.html\#legibilidad Accessed February 8, 2015.

56 Barrio-Cantalejo IM, Simón-Lorda P, Melguizo M, Escalona I, Marijuán MI, Hernando P. Validación de la Escala INFLESZ para evaluar la legibilidad de los textos dirigidos a pacientes. An Sist Sanit Navar 2008; 31: 135-152.

57 Descarga del programa INFLESZ. Available at www.legibilidad.com/home/descargas. html Accessed February 8, 2015.

58 Generador de números aleatorios, sin repetición. Available at http://nosetup.org php_on line/numero aleatorio_2 Accessed February 8, 2015.
59 Friedman DB, Hoffman-Goetz L. A systematic review of readability and comprehension instruments used for print and Web-based cancer information. Health Educ Behav 2006; 33: 352-373.

60 Mayer MA, Leis A, Sanz F. Información sobre salud en internet y sellos de confianza como indicadores de calidad: el caso de las vacunas. Aten Primaria 2009; 41: 534-544.

61 Health On the Net Foundation. Available at www.healthonnet.org Accessed February 8 , 2015

62 Web Médica Acreditada. Available at http://wma.comb.es/es/home.php Accessed February 8, 2015.

63 Agencia de Calidad Sanitaria de Andalucía. Consejería de Igualdad, Salud y Políticas Sociales. Certificación Páginas web. Available at www.juntadeandalucia.es/agenciadecalidadsanitaria/es/certificacion/paginas-web Accessed February 8, 2015.

64 Is the LIDA website assessment tool valid? Available at www.minervation.com/does-lidawork/ Accessed February 8, 2015.

65 Álvarez-Díaz JA. Legibilidad de los formularios de educación y consentimiento en procedimientos de reproducción asistida de la Red Latinoamericana de Reproducción Asistida. Cir Cir 2012; 80: 162-170.

66 Ramírez-Puerta MR, Fernández-Fernández R, Frías-Pareja JC, Yuste-Ossorio ME, Narbona-Galdó S, Peñas-Maldonado L. Análisis de legibilidad de consentimientos informados en cuidados intensivos. Med Intensiva 2013; 37: 503-509.

67 San Norberto EM, Gomez-Alonso D, Trigueros JM, Quiroga J, Gualis J. Vaquero C. Legibilidad del consentimiento informado quirúrgico en España. Cir Esp 2014; 92: 201-207.

68 Ballesteros-Peña S, Fernández-Aedo I. Análisis de la legibilidad lingüística de los prospectos de los medicamentos mediante el índice de Flesch-Szigriszt y la escala INFLESZ. An Sist Sanit Navar 2013; 36: 397-406.

69 Vives M, Young L, Sabharwal S. Readability of spine-related patient education materials from subspecialty organization and spine practitioner websites. Spine 2009; 34: 2826-2831.

70 Theodosiou L, Green J. Emerging challenges in using health information from the internet. Adv Psychiatr Treat 2003; 9: 387-396.

71 Eysenbach G, Köhler C. How do consumers search for and appraise health information on the world wide web? Qualitative study using focus groups, usability tests, and in depth interviews. BMJ 2002; 324: 573-577.

72 Mira Solves JJ, Llinas Santacreu G, Lorenzo Martínez S et al. Preguntas más frecuentes sobre repercusión de la e-salud en la relación entre médico y paciente. Aten Primaria 2010; 42: 112-114.

73 Ávila de Tomás JF, Veiga Paulet JA. Legibilidad de la información sanitaria ofrecida a los ciudadanos. Una aproximación a través del Índice de Flesch. Centro de salud 2002; 10: 589-597. 